\title{
Movement of Lake Sturgeon, Acipenser fulvescens, in a Natural Reach of the Ottawa River
}

\author{
TIM HAXTON
}

Southern Science and Information Section, Ontario Ministry of Natural Resources, Postal Bag 2002, 10 Campus Road, Kemptville, Ontario K0G 1J0 Canada

Haxton, Tim. 2003. Movement of Lake Sturgeon, Acipenser fulvescens, in a natural reach of the Ottawa River. Canadian Field-Naturalist 117(4): 541-545.

A radio-telemetry project was conducted on four Lake Sturgeon in a natural reach of the Ottawa River, Canada. The objective was to ascertain the extent of their movement within a natural river reach. Lake Sturgeon displayed high fidelity to a basin and did not move extensive distances. Maximum distance traveled between tracking locations was $10 \mathrm{~km}$ and mean home range was 1528 ha. Mean distance moved did not significantly differ between seasons. Mean water depth in which Lake Sturgeon were located was $3.5 \mathrm{~m}$. Lake Sturgeon were not located within $52 \mathrm{~km}$ of the upstream dam.

Key Words: Lake Sturgeon, Acipenser fulvescens, radio-telemetry, Ottawa River, Ontario.

Lake Sturgeon, Acipenser fulvescens, are endemic to North America and have declined across their range (Williamson 2003). Populations, once abundant in the Great Lakes, are estimated to be $<1 \%$ of historical levels (Tody 1974 as cited in Caswell et al. 2004). Commercial harvest has been considered the primary cause for their precipitous decline (Harkness and Dymond 1961); however, other stressors such as pollution, habitat degradation, and dam construction have had an impact (Harkness and Dymond 1961; Houston 1987). Dams block migration routes up tributaries to historical spawning areas (Harkness and Dymond 1961; Priegel and Wirth 1971).

Lake Sturgeon are potamodromous, migrating in excess of $200 \mathrm{~km}$ (Kempinger 1988; Rusak and Mosindy 1997; Auer 1999) primarily for breeding purposes (Dumont et al. 1987; Auer 1996; McKinley et al. 1998). Migrations generally end at the base of dams in controlled rivers (Auer 1996; D’Amours et al. 2001). Postspawning migrations are generally back to foraging areas (McKinley et al. 1998). Lake Sturgeon have been found to utilize entire reaches in a controlled river (McKinley et al. 1998). Is this similar for all rivers?

Lake Sturgeon are present in the Ottawa River (Haxton 2002), an altered system with hydro-electric dams constructed along it course. There are several river reaches within the waterbody that are not impounded ("natural"). The objective of this study was to determine the extent of movement by Lake Sturgeon in a natural reach of the Ottawa River over a two-year period and, in particular, if they moved throughout the reach. Also of interest was dams whether impeded further movement. If so, then Lake Sturgeon would be tracked in the vicinity of the dam.

\section{Study Site}

The study was based in Allumette Lake of the Ottawa River; a river that has undergone extensive development for hydro-electric purposes (Haxton and Chubbuck 2002). Allumette Lake is approximately $70 \mathrm{~km}$ in length, delineated on the southeast by the interprovincial bridge on Highway 148 located downstream of Pembroke (Figure 1) and on the northwest by the Rapides des Joachims power generating station at Rolphton 235 road km upstream from Ottawa. Water depths average 10 to $15 \mathrm{~m}$ in this section with a maximum depth of $60 \mathrm{~m}$ near Deep River. This reach is relatively calm (without rapids) except near Petawawa where there are numerous islands, faster currents, and shallow water. The majority of the study took place in a basin approximately $14 \mathrm{~km}$ long, characterized by sand and clay substrate with areas of rock rubble in faster flowing areas and relatively shallow depths with a maximum depth of $16.5 \mathrm{~m}$ (Figure 1).

\section{Methods}

Lake Sturgeon were captured in Allumette Lake late October 1998 with the use of $2.4 \mathrm{~m}$ trapnets set offshore near Desjardinsville, Quebec. Total length (to the nearest $\mathrm{mm}$ ), fork length and weight (to the nearest $10 \mathrm{~g}$ ) were obtained from Lake Sturgeon used in the study. Radio transmitters (model MBFT-6: Lotek Engineering Inc., Aurora, Ontario) were cylindrical with a whip antenna, measuring $11 \mathrm{~mm}$ (diameter) by $59 \mathrm{~mm}$ (length) and weighed $10.3 \mathrm{~g}$ (weight in water $4.6 \mathrm{~g}$ ). The operating frequency was 149.140 to $149.820 \mathrm{MHz}$ (Table 1) with a pulse rate of 29 beeps per minute. The expected life of these transmitters was 746 days. 
TABLE 1. Attributes of Lake Sturgeon with radio transmitters implanted.

\begin{tabular}{ccccc}
\hline \hline Sturgeon Number & Transmitter Frequency & Total length $(\mathrm{cm})$ & Fork length $(\mathrm{cm})$ & Weight $(\mathrm{g})$ \\
\hline 140 & 149.140 & 84.7 & 76.0 & 2900 \\
240 & 149.240 & 90.0 & 80.5 & 3500 \\
320 & 149.320 & 98.0 & 87.5 & 4400 \\
820 & 149.820 & 84.0 & 75.0 & 2675 \\
\hline \hline
\end{tabular}

Lake Sturgeon were anesthetized using tricaine methanesulfonate (MS222) and radio transmitters were surgically implanted. Radio transmitters and operating equipment were sterilized with isopropyl alcohol prior to use. A small incision was made in the abdomen wall, proximal to the midline ensuring the incision was not deep enough to damage internal organs. The incision exposed the peritoneal cavity and the transmitter was inserted into the peritoneum. The whip antenna was coiled inside of the peritoneum to prevent a source of irritation and infection that could be caused by a trailing antenna. The incision was closed with catgut suture material (sized 4-0). Each Lake Sturgeon was injected with Liquamycin $(100 \mathrm{mg} / \mathrm{mL}$ of oxytetracycline hydrochloride) at a dose of $0.08 \mathrm{ml}$ per $\mathrm{kg}$ and held in a recovery tank until fully revived. None displayed any effects from the procedure.

Tracking was conducted from both a boat and an airplane over a $2 \frac{1}{2}$ year period using a STR 100 Telemetry Receiver (Lotek Engineering Inc., Aurora, Ontario). Tracking was generally conducted once or twice a week during the spring and less frequently, once or twice a month, the remainder of the year. When tracking from a boat, a three-element folding antenna was used. Attempts were made to pinpoint the Lake Sturgeon, first by triangulation, then by closing in on the location in relation to the strength of the signal. Once a location was determined, UTM co-ordinates were obtained from a GPS unit. When using the plane to track, antennae were mounted on both wings. A switch box (ACU_1) was used to determine what side of the plane the signal originated. Locations were mapped as accurately as possible onto maps of the rivers and UTM co-ordinates later assigned to each point. A Walleye (Sander vitreus) telemetry project was conducted concurrently with this study (Haxton and Punt 2000*). Therefore, the entire length of the river reach was flown when tracking, including several reaches downstream.

UTM co-ordinates were entered onto an Access database along with the pertinent information about each tracking location (fish number, date, time). These co-ordinates were transferred into ArcView (Environmental Systems Research Institute, Redlands, California, USA) and a point coverage was made of all tracking locations. For tracking purposes, Lake Sturgeon were labeled by the frequency of the transmitter (i.e. the Lake Sturgeon with the radio transmitter of 149.820 was labeled Lake Sturgeon 820).
Distance traveled was determined by using the measure feature in ArcView. For analysis purposes, the year was divided into four seasons: Spawn (May June); Summer (July - August); Fall (September December); and Winter (January - April). An ANOVA was conducted on $\log _{10}$ transformed distance data to ascertain if there was a difference in mean movement between seasons. A minimum convex polygon home range was calculated for each Lake Sturgeon using the Animal Movement Analysis Extension (Hooge 2000*). In all cases, the home range extended onto land. Home ranges were calculated only for the river portion by tabulating the area where the home range and water polygons overlapped.

Depth of Lake Sturgeon occurrence was determined by overlaying their location onto a bathymetry map. The general depth of the area was used. It was assumed Lake Sturgeon were on bottom at time of tracking. An ANOVA was conducted to determine if there was a difference in depth utilized based on season.

Statistical analysis was conducted using SYSTAT 10.2 (SYSTAT Software Inc. Richmond, California, USA) with significance level determined at $P=0.05$.

\section{Results}

Mean size of Lake Sturgeon in this study was $89.2 \mathrm{~cm}$ total length (Table 1). Radio tracking was found to be most effective and efficient from an airplane and subsequently was the primary means of tracking. Lake Sturgeon were tracked on 43 different occasions, for 110 observations (Figure 1). Three or more sturgeon were located on $48.8 \%$ of the trackings. The number of times each sturgeon was located was between 23 and 32 occasions (Table 2). All sturgeon were located in 2001, the last year of the study.

Lake Sturgeon displayed fidelity to the same basin that they were originally sampled, primarily concentrated offshore of Desjardinsville opposite Pembroke (Figure 1). There was some movement outside, or to the periphery, of the basin. Sturgeon 820 moved to the faster flowing water near the lighthouse off Île Leblanc from January through until early April 1999 but then returned to the basin by May. It later moved upstream to the Petawawa Islands for at least a week in July 1999. Sturgeon 140 was located in this vicinity of the lighthouse at the end of April 1999 and Sturgeon 240 was located there in September 1999. Sturgeon 320 moved into Hazley Bay, a small shallow Bay with depths less than $2.4 \mathrm{~m}$, on two separate 


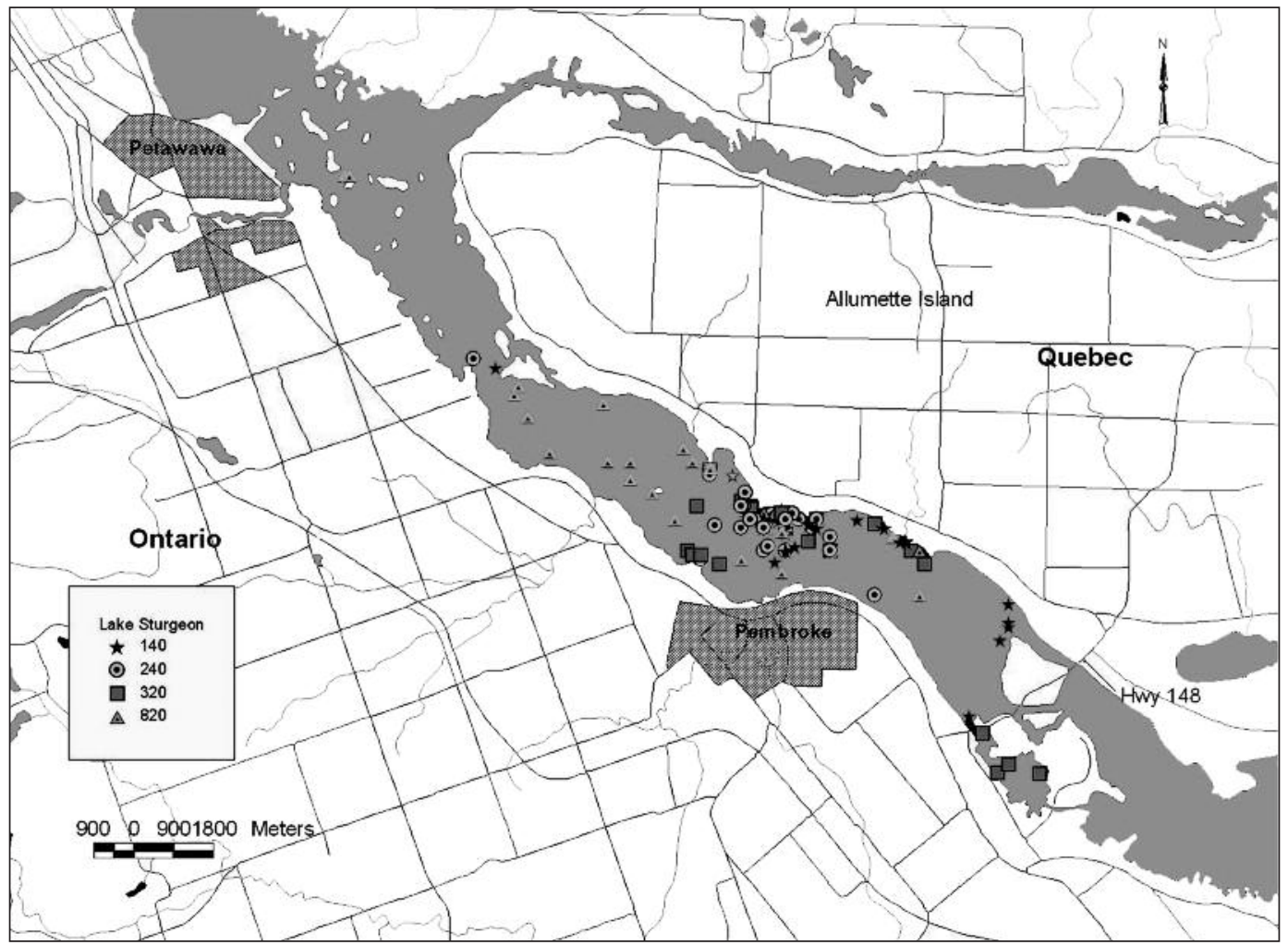

FIGURE 1. Lower portion of Allumette Lake (Ottawa River) with Lake Sturgeon tracking locations identified.

occasions. And sturgeon 140 was located at the top of Lower Allumette Rapids in March of 1999 and 2001. Lake Sturgeon were not tracked within $52 \mathrm{~km}$ of the dam.

The average distance moved between trackings was $2.5 \mathrm{~km}$. The maximum distance traveled between trackings was $10.6 \mathrm{~km}$ by Lake Sturgeon 820 between 13 July and 10 August. Average movement between seasons was not significantly different (ANOVA $3,101, F=0.718, P=0.544$ ). Average home range for the four Lake Sturgeon was 1528 ha (Table 2).

Lake Sturgeon were generally found in shallow water; mean depth was 3.5 (2.1 S.D.) m. There was variation in mean depth of Lake Sturgeon between seasons (Figure 2); however, these differences were not significant $\left(\mathrm{ANOVA}_{3,105}, F=1.415, P=0.242\right)$.
Lake Sturgeon were sometimes located in areas with water depths up to $12 \mathrm{~m}$.

\section{Discussion}

In contrast to the findings of McKinley et al. (1998), Lake Sturgeon in the present study did not move extensively throughout the reach but displayed high fidelity to the one particular basin, sometimes leaving the basin but returning later. Homing or site fidelity by Lake Sturgeon has previously been described (Threader and Brousseau 1986; Fortin et al. 1993; Rusak and Mosindy 1997; Auer 1999; Caswell et al. 2004). This area of the river is characterized by a sandy, clay substrate, which should be productive for benthic invertebrates, the primary source of prey for sturgeon. Juvenile sturgeon will remain in areas where there is

TABLE 2. Average home range, average movement, number of times tracked and last date tracked for each Lake Sturgeon

\begin{tabular}{ccccc}
\hline \hline $\begin{array}{c}\text { Sturgeon } \\
\text { number }\end{array}$ & $\begin{array}{c}\text { Number of } \\
\text { times tracked }\end{array}$ & $\begin{array}{c}\text { Home } \\
\text { range (ha) }\end{array}$ & $\begin{array}{c}\text { Average } \\
\text { movement (km) }\end{array}$ & $\begin{array}{c}\text { Last date } \\
\text { tracked }\end{array}$ \\
\hline 140 & 26 & 1645 & 2.5 & 25 May 2001 \\
240 & 32 & 1066 & 1.5 & 25 May 2001 \\
320 & 23 & 1348 & 2.6 & 25 May 2001 \\
820 & 29 & 2054 & 3.2 & 7 November 2001 \\
\hline \hline
\end{tabular}




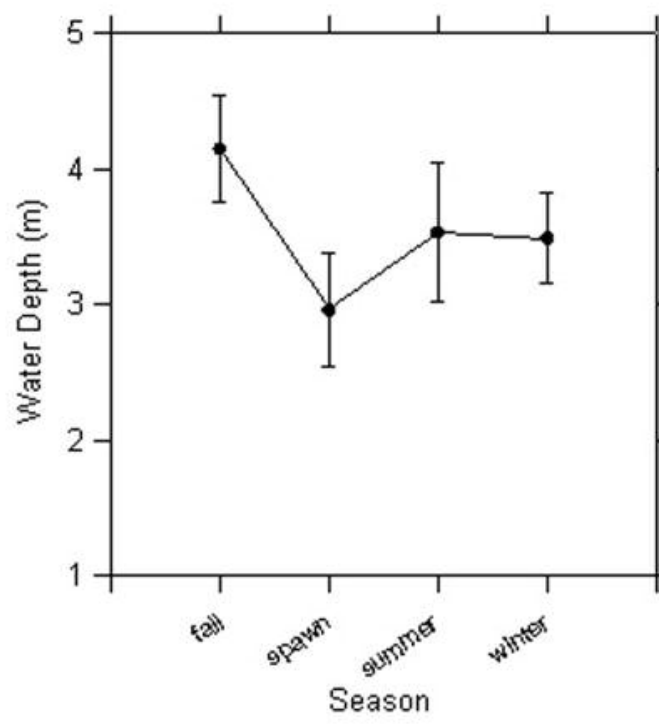

FIGURE 2. Mean depth of Lake Sturgeon by season (error bars in standard deviations).

moderate abundance of a prey species (Chiasson et al. 1997). Lake Sturgeon should not have been restricted upstream movement as Walleye in the concurrent study traveled up to $70 \mathrm{~km}$ to the base of the Rolphton Dam (Haxton and Punt 2000*).

Unfortunately, neither sex, stage of maturity nor age was assessed when implanting radio transmitters. Lake Sturgeon attains sexual maturity in lower Ottawa River reaches at $92 \mathrm{~cm}$ and $83 \mathrm{~cm}$ total length for females and males, respectively (Dubrueil and Cuerrier 1950), which would suggest that these sturgeon could have been mature. Recent studies on Lake Sturgeon maturity in this river reach, however, suggest that maturity is not attained until a total length of $115 \mathrm{~cm}$ (Haxton, unpublished data). Therefore, Lake Sturgeon used in this study were probably juveniles, at least at the time when radio transmitters were implanted. However, since sex and stage of maturity were not assessed, it is difficult to ascertain whether lack of movement to upper portions of the river reach was due to spawning periodicity (Roussow 1957), habitat requirements fulfilled within the basin, or prey abundance for juveniles (Chiasson et al. 1997).

Lake Sturgeon in this study were found in relatively shallow water. This is comparable to a $2-6 \mathrm{~m}$ preference by Lake Sturgeon in the Groundhog River in northern Ontario (Seyler 1997) and depths $<2.5 \mathrm{~m}$ in the Mattagami River (McKinley et al. 1998). Lake Sturgeon, however, were most frequently located in water depths $>6 \mathrm{~m}$ in Rainy Lake (Rusak and Mosindy 1997). Lake Sturgeon usually inhabit waters from 4 to $9 \mathrm{~m}$ (Houston 1987). The mean water depth utilized may have been skewed by the inability to locate all Lake Sturgeon on each tracking. Radio transmitter signal decreases as their depth increases. Generally, when radio transmitters are in depths greater than $9 \mathrm{~m}$, the ability to detect a signal is low. While this study did locate Lake Sturgeon in depths of $12 \mathrm{~m}$, I feel the reason we were not able to locate each sturgeon during each flight was because some were in deep water and the radio transmitter was weak. Therefore, the mean depths reported as preferred here may be low.

While there were some inherent problems with this project (i.e., Lake Sturgeon were not studied intensely enough to assess seasonal movement and habitat selection; the number of sturgeon tracked was small $(n=4)$; and tracking was primarily geared around Walleye), this study did elucidate some details about the extent of sturgeon movement in a natural reach. Although movement by Lake Sturgeon in this study was limited, this did not appear to be due to the presence of dams as these were beyond the areas occupied.

\section{Acknowledgments}

Several key people that were instrumental in the completion of this study include: Gord Pearson, Pilot, Ontario Ministry of Natural Resources; Kirby Punt, Senior Fish and Wildlife Technician, Ontario Ministry of Natural Resources, Pembroke District; Pembroke Outdoors Sportman's Club (who spent many hours tracking Walleye and Lake Sturgeon); and several Pembroke District staff.

\section{Documents Cited (marked $*$ in text)}

Haxton, T., and K. Punt. 2000. Walleye telemetry study to determine the spawning locations in Lac des Chats and Allumette Lake sections of the Ottawa River. Ontario Ministry of Natural Resources, Pembroke District, Pembroke, Ontario. Unpublished report.

Hooge, P. N. 2000. Animal Movement Analysis Arcview Extension. Alaska Biological Science Centre, Glacier Bay Field Station.

\section{Literature Cited}

Auer, N. A. 1996. Response of spawning Lake Sturgeon to changes in hydroelectric facility operation. Transactions of the American Fisheries Society 125: 66-77.

Auer, N. A. 1999. Population characteristics and movements of Lake Sturgeon in the Sturgeon River and Lake Superior. Journal of Great Lakes Research 25: 282-293.

Caswell, N. M., D. L. Peterson, B. A. Manny, and G. W. Kennedy. 2004. Spawning by lake sturgeon (Acipenser fulvescens) in the Detroit River. Journal of Applied Ichthyology 20: 1-6.

Chiasson, W. B., D. L. G. Noakes, and F. W. H. Beamish. 1997. Habitat, benthic prey, and distribution of juvenile Lake Sturgeon (Acipenser fulvescens) in northern Ontario rivers. Canadian Journal of Fisheries and Aquatic Science 54: 2866-2871.

D'Amours, J. S. Thibodeau, and R. Fortin. 2001. Comparison of Lake Sturgeon (Acipenser fulvescens), Stizostedion spp., Catostomus spp., Moxostoma spp., quillback (Carpoides cyprinus) and mooneye (Hiodon tergisus) larval drift in Des Prairies River, Quebec. Canadian Journal of Zoology 79: 1472-1489. 
Dubreuil, R., and J. P. Cuerrier. 1950. Cycle du maturation des glands génitales chez l'esturgeon de lac (Acipenser fulvescens, Raf.). Institut de Biologie géneral et de Zoologie, Université de Montréal. 50 pages.

Dumont, P., R. Fortin, G. Desjardins, and M. Bernard. 1987. Biology and exploitation of Lake Sturgeon (Acipenser fulvescens) in the Quebec waters of the SaintLaurent River. Pages 57-76 in Proceedings of a workshop on Lake Sturgeon (Acipenser fulvescens). Edited by C. H. Olver. Ontario Fisheries Technical Report Series Number 23.

Fortin, R., J-R. Mongeau, G. Desjardins, and P. Dumont. 1993. Movements and biological statistics of Lake Sturgeon (Acipenser fulvescens) populations from the St. Lawrence and Ottawa River system, Quebec. Canadian Journal of Zoololgy 71: 638-650.

Harkness, W. J. K., and J. R. Dymond. 1961. The lake sturgeon: the history of its fishery and problems of conservation. Ontario Department of Lands and Forests, Fish and Wildlife Branch, Toronto. 121 pages.

Haxton, T. J. 2002. An assessment of Lake Sturgeon (Acipenser fulvescens) in various reaches of the Ottawa River. Journal of Applied Ichthyology 18: 449-454.

Haxton, T., and D. Chubbuck. 2002. Review of the historical and existing natural environment and resource uses on the Ottawa River. Ontario Ministry of Natural Resources, Science and Information Branch, Southcentral Science and Information Section Technical Report \#119. 76 pages.

Houston, J. J. 1987. Status of the Lake Sturgeon, Acipenser fulvescens, in Canada. Canadian Field-Naturalist 101: 171-185.

Kempinger, J. J. 1988. Spawning and early life history of Lake Sturgeon in the Lake Winnebago system, Wisconsin. American Fisheries Society Symposium 5: 111-122.
McKinley, S., G. Van Der Kraak, and G. Power. 1998. Seasonal migrations and reproductive patterns in the Lake Sturgeon, Acipenser fulvescens, in the vicinity of hydroelectric stations in northern Ontario. Environmental Biology of Fishes 51: 245-256.

Priegel, G. R., and T. L. Wirth. 1971. The lake sturgeon. Its life history, ecology and management. Wisconsin Department of Natural Resources, Madison, Wisconsin. Publication 270-277.

Roussow, G. 1957. Some considerations concerning sturgeon spawning periodicity. Journal of the Fisheries Research Board of Canada 14: 553-572.

Rusak, J. A., and T. Mosindy. 1997. Seasonal movements of Lake Sturgeon in Lake of the Woods and the Rainy River, Ontario. Canadian Journal of Zoology 74: 383-397.

Seyler, J. 1997. Adult lake sturgeon (Acipenser fulvescens) habitat use, Groundhog River. Ontario Ministry of Natural Resources, Northeast Science and Technology. Timmins, Ontario. Report TR-035. 20 pages.

Threader, R. W., and C. S. Brousseau. 1986. Biology and management of the lake sturgeon in the Moose River, Ontario. North American Journal of Fisheries Management 6: 383-390.

Tody, W. H. 1974. Whitefish, sturgeon, and the early commercial fishery. Pages 45-60 in Michigan Fisheries Centennial Report 1873 - 1973. Michigan Department of Natural Resources, Lansing, Michigan.

Williamson, D. F. 2003. Caviar and conservation: Status, management and trade of North American Sturgeon and Paddlefish. TRAFFIC North America. World Wildlife Fund, Washington, D.C.

Received 13 November 2001

Accepted 7 May 2004 